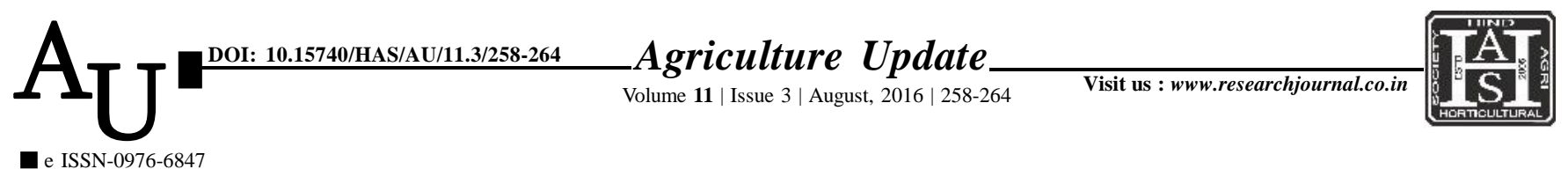

\title{
Reserach Aвтісl: : Constraints faced by mustard growers of Bharatpur, Rajasthan
}

\section{D.S. BHATI, Y.K. SHARMA AND S.K. SHARMA}

Article Chronicle: Received :

29.10.2015;

Revised :

30.06.2016;

Accepted :

11.07.2016

KEY Words:

Constraint, Technical, Economical,

Infrastructural, Crop
Author for correspondence :

\section{D.S. BHATI}

Krishi Vigyan Kendra, AJMER (RAJASTHAN) INDIA

See end of the article for authors' affiliations
SUMMARY : This research study was conducted in Bharatpur district of Rajasthan, where Directorate of Rapeseed-Mustard Research is situated. After interviewing three hundred farmers personally who belong to different categories of farmers was found that crop failure due to aberrant weather, high cost of fertilizers, lack of knowledge about plant protection measures and technical staff working in the field is not available when needed were the most perceived constraints by the all three categories of farmers.

How to cite this article : Bhati, D.S., Sharma, Y.K. and Sharma, S.K. (2016). Constraints faced by mustard growers of Bharatpur, Rajasthan. Agric. Update, 11(3): 258-264, DOI : 10.15740/HAS/AU/11.3/258-264. 